\title{
Notes on works for documenta 14, Athens \& Kassel, 2017
}

With all its eyes the creature-world beholds

the open. (Rilke 1975, 77)

... art is continually haunted by the animal. (Deleuze and Guattari 1994, 184)

How does the angel come to be an animal? (Serres 1999, 103)

\section{Criollo}

A solitary horse stands at the threshold to Central Park, New York. The camera rotates slowly around the equine creature and comes to rest face on, revealing the animal framed by the lights and dawn traffic of Sixth Avenue / Avenue of the Americas. The horse remains motionless, almost statuesque, its back to the Manhattan intersection. Its ears turn attentively, scanning the sonic environment: engines and exhausts of cars and yellow cabs; air brakes of lorries and delivery trucks; the footfall of a few passing pedestrians en route to or from work; the condensing breath of early morning joggers braving the snow. What is the agency of this solitary animal? Is it liberated, lost or abandoned? Is it an angel, apparition or gift? Is it a harbinger of unspecified change or envoy of a revolution to come?

We move to a close up. The animal meets our gaze as the camera traces its physical presence in space, a presence doubled in the distorted traffic and animal noise of the film's soundtrack. Amid the emerging clamour of the awakening city, an exchange of looks enacts an unsettling animalséance (Derrida 2008, 4):

The eyes of an animal when they consider a man are attentive and wary. The same animal may well look at other species in the same way. He does not reserve a special look for man. But by no other species except man will the animal's look be recognized as familiar. Other animals are held by the look. Man becomes aware of himself returning the look. (Berger $1980,13)^{1}$

The human-animal gaze - a paradoxical tension between captivation ${ }^{2}$ and uncertainty - is held until the animal turns its head and looks away, almost indifferent to our all too human gaze. For all our proximity to (and captivation with) a fellow sentient being, embodied in a momentary meeting of eyes, do we not yet gaze upon one another across a 'narrow abyss of non-comprehension' (Berger 1980, 13)? Nonetheless, in such moments of mutual incomprehension does there not yet reside an animal interpellation? As Donna Haraway writes:

... animals "hail" us to account for the regimes in which they and we must live. We "hail" them into our constructs of nature and culture, with major consequences of life and death, health and illness, longevity and extinction. We also live with each other in the flesh in ways not exhausted by our ideologies. (Haraway 2003, 17)

Before we can grasp the consequences of this strange meeting, the horse - an apparition at the threshold - begins to move, walking steadily into the interior of the park. Is

\footnotetext{
${ }^{1}$ Derrida, caught naked and exposed before the 'insistent gaze' of his cat, relates his struggle to overcome feelings of embarrassment and shame, as nakedness is a condition which normatively distinguishes animals from men to the extent that animals are deemed to be 'naked without knowing it' (Derrida 2008, 4).

${ }^{2}$ For a discussion of Heidegger's reading of the animal and captivation, see Agamben 2004, 49-56.
} 
the creature trying to shake us off? Or is it beckoning us to follow its path to 'the open'? ${ }^{3} \mathrm{We}$ travel alongside the horse, the camera tracing its 'animal surface' ${ }^{4}$; the travelling gimbal shot (a human/non-human collaboration between operator and apparatus ${ }^{5}$ ) forms a moving copresence with the animal's muscles and snorts of breath; the animal's biopower echoed in the resounding of hooves which continue to resonate as the horse disappears into the dark and snow-lined folds of Central Park. ${ }^{6}$ However, as the image fades and the horse ultimately moves 'upon a different course' - abandoning us to the fate of remaining 'spectators always' (Rilke 1975, 79, 81) - the indeterminate sound of its movement remains to haunt the screen and further evoke the sense of the non-human animal as spectre haunting the political imaginary:

[Horses] are reduced to an existence as the ghosts of modernity, and the more they forfeit their worldly presence, the more they haunt the minds of a humanity that has turned away from them. [...] [T] he rhythmic pounding of the horse's hooves that set the ground quivering... evokes something, something dormant in the earth, in the hooves and in the air: the possibility that matter can tremble, can quiver, can be knocked, banged, rubbed and given sound; the possibility of the sound and the vibration... creating resonance in the earth, friction in the air, sound waves all around. (Raulff 2017, 11, 339)

This apparition of a lone horse at an urban intersection may conjour the criollo as revenant of the animal which precipitated the scene of the final collapse of Friedrich Nietzsche. On 3 January 1889, the German philosopher witnessed a horse being flogged by the driver of a cab in the Piazza Carlo Alberto in Turin. In tears, the philosopher flung his arms around the horse's neck before collapsing. Accounts of Nietzsche's life read this act as a herald of the thinker's descent into a mute interiority and madness (See, for example, Hayman 1981, 334335). ${ }^{7}$ The shadow of Nietzsche's act of interspecies solidarity was a catalyst for the image which served to sustain the development of this film over the three years of its making. However, the origins of the film lie in an altogether different narrative and location.

\footnotetext{
${ }^{3}$ For key discussions of the Eighth Elegy of Rilke's Duino Elegies in relation to the animal and 'the open' see Heidegger (1992), Agamben (2004) and Santner (2006).

${ }^{4}$ As Ron Broglio writes: 'The surface can be a site of productive engagement with the world of animals.' (Broglio 2011, xvii)

5 To borrow terms from Bruno Latour, a film crew represents 'a collective of humans and non-humans', where the process of film-making necessitates 'the folding of humans and non-humans into each other'. (See Latour 1999, 174-215) The terms of my suggested comparison revolve around the pun contained in 'to shoot', its being associated both with the purpose of the actants of gun (the subject of Latour's analysis) and camera alike.

${ }^{6}$ This final sequence of the film maps an almost imperceptible 'becoming-animal' (Deleuze and Guattari 1988, 232ff) of the camera, which precipitates a vital shift in the subject position of the gaze: from a human-animal encounter to 'an animal relationship with the animal' (Deleuze and Parnet 1989, 14:22 - 14:25).

${ }^{7}$ For a discussion of this event see the editorial of Art \& Research 4 (1) by Birrell and Broglio (2011). See also the documenta 14 daybook in which participating artists were invited to identify a date in history with an accompanying image which was important to them. I selected 3 January 1889 and an image of Nietzsche from a decade later, taken by Hans Olde, which captures the philosopher in the grip of stroke-induced paralysis. The short entry concludes: 'Visible in his final silence is a defiant animal resonance, wild staring eyes fixated in selfdissolving, intoxicating rapture.’ Latimer and Szymczyk (2017), np [Entry for 20 August].
} 
Criollo (Figure 1) is inspired by Tschiffely's Ride (1933), an autobiographical account of a 10,000 mile equestrian journey from Buenos Aires to New York (1925-1928) by SwissArgentine horseman, Aimé Félix Tschiffely, riding two Argentine criollos, Mancha and Gato. The criollo, a mixture of Arab and Barbary breeds, was introduced into Argentina by Spanish Conquistadors in 1535. When Buenos Aires was re-taken by the indigenous Indian population, the criollo horses were left feral, often roaming long distances for sustenance. In the nineteenth century Wars of Independence fought against colonial Spain, the criollo populated the revolutionary cavalry of Argentine leader, José de San Martin. Later, the breed became synonymous with Argentine gauchos farming the pampas, and the criollo became renowned throughout Latin America for their stamina, calm temperament and capacity for hard work. Today the criollo has an ambivalent fate; on one level the animal is celebrated and promoted in festivals and parades, such as the annual Tradition Day Festival in San Antonio de Areco and other towns and cities across Argentina. ${ }^{8}$ However, these festivals which seek to promote and preserve the heritage of horsemanship, appear as 'time out of joint' when - in contrast to their ritual celebration as cultural signifiers and as working animals - criollo horses at the end of their working lives are routinely transported to Europe for slaughter as horse meat. ${ }^{9}$ The currents which flow through celebrations of equestrian heritage, run counter to the domination of mechanized transportation, industrialized farming techniques and global meat industry, watermarks of a century which witnessed 'the exodus of the horse from human history'(Raulff 2017, 5). The twentieth century oversaw the decline and eclipse of the horse as the companion-species of human economic, political, cultural and military expansion and domination. As Ulrich Raulff describes in his recent Farewell to the Horse: The Final Century of Our Relationship (2017), the horse, once 'the central vector of historical land power' (Raulff 2017, 346) has all but disappeared from our daily lived reality, taking on an increasingly ‘imaginary and chimeric form’ (Raulff 2017, 11). For John Berger, writing in his classic essay 'Why Look at Animals?' (1977), the absence of working animals from the world of corporate capitalism is evidence of an irrevocable 'rupture' between man and nature, between man and animal, representing a scene of 'historical loss, to which zoos are a monument' (Berger 1980, 37). 'Before this rupture,' Berger laments, 'animals constituted the first circle of what surrounded man... They were with man at the centre of his world. [...] In the last two centuries, animals have gradually disappeared. Today we live without them.' (Berger 1980, 12, 21) ${ }^{10}$ Today, then, the physical presence of horses in public space appears as something of a socio-historical anachronism and an unlikely candidate for the attentions of contemporary art in the context of globalization. However, as Giorgio Agamben claims, it is only through disjunction and anachronism that one truly adheres to the contemporary (Agamben 2009, 41).

The name 'criollo' is a variant of creole and holds similar associations of 'cultural, social and linguistic mixing' and the relational 'entanglement' which critics such as Stuart

\footnotetext{
8 Tradition Day is held on 10 November to mark the anniversary of the birth of Argentine writer, José Hernández (1834-1886), author of the epic poem, The Gaucho Martín Fierro (1872). Martín Fierro is a classic of Argentine gauchesco poetry and Jorge Luis Borges regarded it as 'the most lasting work we Argentines have written', and echoes the opinion of the Argentine poet, Leopold Lugones (1874-1938), that 'this poem should be for us what the Homeric poems were for the Greeks' (Borges 1999, 420). An English version of Martín Fierro was published by the Glasgow-born translator, Walter Owen (1884-1953).

${ }^{9}$ Argentina is regarded as the world's leading exporters of horses for the meat industry with a substantial share of its market being the EU: 'In spite of its love for horses, Argentina is the world's leading exporter of horse meat having shipped 23.880 tons in 2010, valued 75 million US dollars according to the country’s Animal health and Agro-food quality service, SENASA.' http://en.mercopress.com/2011/05/04/argentina-leads-inhorse-meat-exports-23.880-tons-in-2010 [Date accessed: 27 November 2017]

${ }^{10}$ Filipa Ramos describes Berger's essay as an articulation of 'longing for a lost animal presence in our contemporary world' (Ramos 2016, 18).
} 
Hall and Édouard Glissant, identify with the creolization of globalized, post-colonial cultures (See: Enwezor et al. 2002; Glissant 1989). In its name and in its history, then, the criollo combines North African and Middle Eastern bloodlines, the culture of colonialism and wars of liberation, postmodernity and post-colonialism, and contemporary contexts of globalisation and migration.

'Perhaps', Deleuze and Guattari muse, 'art begins with the animal' (Deleuze and Guattari 1994, 183). The beginning of the film Criollo, in its transit from proposal to project, was a 6-year old criollo gelding, Ahi Veremos Resero. Raised on the estancia El Cardal, Ayacucho, Argentina, Ahi was gifted to the film by Oscar Solanet, the son of Dr Emelio Solanet, the veterinarian who donated Mancha and Gato to Tschiffely in the 1920s. Ahi was transported from Buenos Aires to New York via air and road transportation, and he arrives in New York as an apparition: an animal-angel-messenger which appears and disappears in the half-light of a winter dawn: As Michel Serres reminds us: 'In the most ancient traditions, messenger-angels don't necessarily take only human form...' (Serres 1999, 25). But as a 'criollo' (a variant of ‘creole') Ahi is also one of Michel Serres' 'mingled bodies' (the subtitle of his The Five Senses [2008]). In this context, it is perhaps important to recall that Tschiffely's Ride was first published in 1933, the year Hitler that seized power in Germany and implemented a biopolitics of racial purity to immunize the volk against contamination from the non-Aryan other. Although Tschiffely eschews any overt political reading of his ride, his dedication to the book positions the published account as a record of resistance to any biopolitics founded upon nationalism and racism. The dedication reads:

To all lovers of the horse and the wide open spaces;

And to many friends - of whatever race, nationality or creed -

Who did their utmost to make rough places smooth. (Tschiffely 1933, v)

Tschiffely's dedication resonates strongly today as we witness the resurgence of a biopolitics of intolerance of the other and the strengthening of national borders across Europe and North America. Although not undertaken for economic reasons, in its remarkable feat of endurance, crossing of border territories and war zones, and its arduous and determined passage North, Tschiffely's Ride presages countless contemporary migrations. ${ }^{11}$ Furthermore, Tschiffely's Ride, seems prescient of recent trajectories in post-humanism and critical theory. Tschiffely repeatedly refers to the two criollos, Mancha and Gato - without whom he would never have completed his epic journey - as his 'pals' and 'companions'. ${ }^{12}$ And there is a telling moment in Guatemala, when he takes a swim with the horses in Lake Atitlan, relating: 'we bathed and enjoyed ourselves like three beings of the same flesh and blood' (Tschiffely 1933, 321). In this fleeting moment an interzone of relational identity opens up in a joyous encounter where species meet, producing a third space beyond human-animal binaries which resonates with concepts of 'becoming-animal' (Deleuze and Guattari 1998), 'companion species' (Haraway 2003), and 'trans-species solidarity' (Braidotti 2006). ${ }^{13}$

\footnotetext{
11 Tschiffely's contrasting of 'rough' and 'smooth' places on his equestrian journey perhaps chimes with Deleuze and Guattari’s reading of 'smooth' and ‘striated' space. See Deleuze and Guattari 1988, 474-500.

12 For an interesting discussion of friendship within and between species, see James Serpell, 'Humans, Animals, and the Limits of Friendship' (Porter and Tomaselli 1989, 111-129) and Serpell, 2008.

${ }^{13}$ Later, in a further displacement of anthropocentrism which perhaps echoes E. T. A. Hoffmann's The Life and Opinions of the Tomcat Murr, Tschiffely will pen a version of the 10,000 mile epic journey retold from the perspective of the horses (Tschiffely, 1943).
} 
Reconfigurations of human-animal relations in posthumanist discourses re-refashion the distinction between zoe and bios, a distinction which structures the biopolitical conception of 'bare life' as articulated by Giorgio Agamben. For Agamben, the regime of biopolitics, the power of a sovereign authority over the life and death of its subjects, is epitomized in the modern period in the concentration camp, which Agamben views as a threshold experience of modernity. Absolute power over life and death in the camps is exemplified in the emaciated and defeated figure of the Muselmann, a living being on their last legs, devoid of all dignity, barely human, resigned to a fate worse than death. Derived from the derogatory reference to Muslim, the Muselmann exists on the level of a non-human animal and was often likened to 'donkeys' and 'camels' (Agamben 2002, 44). According to Agamben, the Muselmann traces the transit from human to inhuman / non-human:

The Muselmann in some sense marked the moving threshold in which man passed into nonman... the Muselmann is an indefinite being in whom not only humanity and non-humanity, but also vegetative existence and relation, physiology and ethics, medicine and politics, and life and death continuously pass through each other. [...] the camp, as the exemplary extreme situation, thus allows for the determination of what is inhuman and human and, in this way, for the separation of the Muselmann from the human being... The Muselmann is not only or not so much a limit between life and death; rather, he marks the threshold between the human and the inhuman. (Agamben 2002, 47-55)

The threshold figure of the Muselmann, one who inhabits (or endures) in the camp a realm between the human and the inhuman / non-human, reduced to the 'bare life' of animal existence, draws a distinction between two conditions of life - zoe and bios - which each hold implications for the understanding of biopolitics and the question of the animal. According to Agamben:

The Greeks had no single term to express what we mean by the word "life." They used two terms that, although traceable to a common etymological root, are semantically and morphologically distinct: zoe, which expressed the simple fact of living common to all living beings (animals, men, or gods), and bios, which indicated the form or way of living proper to an individual or a group... (Agamben 1998, 1) ${ }^{14}$

For Aristotle, 'man is by nature a political animal [Politikon zoon]' (Aristotle 1981, 59). That which distinguishes men as political animals 'whose nature is to live, in a polis (state)' (Aristotle 1981, 59) from the other animals, for Aristotle, is language and speech (as distinct from voice, through which animals can articulate pleasure or suffering but neither the cause nor the justice or injustice of such pleasure or suffering [Aristotle 1981, 60]). A further distinction is drawn between zoe and bios in Aristotle's defense of slavery where the bodies of slaves are aligned with the bodies of animals:

The use made of slaves hardly differs at all from that of tame animals: they both help with their bodies to supply our essential needs. It is then part of nature's intention to make the bodies of free men to differ from those of slaves, the latter strong enough to be used for

\footnotetext{
${ }^{14}$ Derrida dismisses the distinction between zoe and bios drawn by Agamben on the grounds that Agamben misinterprets zoe as 'bare’: ‘... zoe designates a life that is qualified, and not 'bare”.' (Derrida 2009, 327), and arguing that there is no absolute division between biopolitics and zoopolitics to be found in Aristotle, explaining: ' ... man is that living being who is taken by politics: he is a political living being, and essentially so. In other words, he is zoo-political, that's his essential definition, that's what is proper to him, idiom; what is proper to man is politics; what is proper to this living being that nan is, is politics, and therefore man is immediately zoo-political, in his very life, and the distinction between bio-politics and zoo-politics doesn't work at all here.' (Derrida 2009, 348-9).
} 
necessary tasks, the former erect and useless for that kind of work, but well suited for the life of a citizen of a state [Politikos bios] (Aristotle 1981, 69) ${ }^{15}$

It is here that we find the roots of a distinction between zoe and bios, between 'bare life' and political society, which structures biopolitics and the exercise of biopower. For Foucault, 'bio-power' is embodied in the right of the sovereign to exercise his authority over the life and death of living bodies subject to his control, and that this domination of the body maps onto the development of the institutions of capitalist power relations - in methods of the measurement and control of populations and workforces - to the extent that 'biopower was without question an indispensable element in the development of capitalism' (Foucault 1981, 140-1). That 'deployments of power are directly connected to the body - to bodies, functions, physiological processes, sensations, and pleasures’ (Foucault 1981, 151-2) would suggest that capitalism exercises power not so much in the field of biopolitics but in the territory of zoopolitics. Arguably, Foucault's biopolitics (which he ultimately articulates in the context of sex and sexuality) can be equally applied to the ethico-political context of the animal. It is here we might further delineate the distinction between zoe and bio in terms of an alignment between animal / bare life (zoopolitics), on the one hand, and the life of the citizen (biopolitics), on the other. Ultimately, it is not the separation of these two realms that interests us here, but their strategic overlap in 'a zone of irreducible indistinction':

... the realm of bare life - which is originally situated at the margins of the political order gradually begins to coincide with the political realm, and exclusion and inclusion, outside and inside, bios and zoe, right and fact, enter into a zone of irreducible indistinction... When its borders begin to be blurred, the bare life that dwelt there frees itself in the city and becomes both subject and object of the conflicts of the political order, the one place for both the organization of State power and emancipation from it.... If anything characterizes modern democracy as opposed to classical democracy, then, it is that modern democracy presents itself from the beginning as a vindication and liberation of zoe, and that it is constantly trying to transform its own bare life into a way of life and to find, so to speak, the bios of zoe. (Agamben 1998, 1, 9)

When we draw upon the term biopolitics we recognize the entanglement, intertwining or 'interlacement' (Agamben), of zoe and bios - a transversal territory where we must read the (animal) body of 'bare life' as both a site of 'the organization of State power' (in permits, licenses, quarantine stations, vaccinations, etc.) and the locus of the animal's 'emancipation' from power (in its identity as animal, as companion species and not as anthropomorphic allegory) through the vitalist agency of what Rosi Braidotti refers to as 'the generative force of zoe' (Braidotti 2006, 210). When one speaks of biopower, then, one designates, in one and the same breath (anima), both power over and power of the animal, when power over is resisted by the same power of bare life.

Braidotti's focus upon the critical territory of zoe in the promotion of a postanthropocentric 'bio-centred egalitarianism' (Braidotti 2006, 99) - extending readings of both Agamben's concept of 'bare life' and Deleuze and Guattari's 'nomadology' and 'becominganimal' - further refines the concepts of biopower and biopolitics. In addition, the generative and emancipatory biopolitical/zoopolitical formation of bios/zoe as 'a major transversal force that cuts across and reconnects previously segregated domains' (Braidotti 2006, 99) holds many parallels with the concept of 'global creolization' (Braidotti 2006, 68) - a concept integral to the development of Criollo.

\footnotetext{
${ }^{15}$ Agamben also associates the body of the slave with the animal body, an 'unresloved remnant' in a philosophy 'irreducibly drawn and divided between animality and humanity’ (Agamben 2004, 15).
} 
In Criollo, the animal appears and disappears at an urban intersection, a crossroads which is also a threshold.

The wretched of the earth are messengers of an extraordinary state which is unknown to us. They roam the streets... they disappear.... and then suddenly re-appear on a street corner; they are phantoms but they are real, in this sense they pierce through our illusory realities... (Serres 1999, 20)

It was integral to the project that Criollo be filmed at the Artists' Gate entrance to Central Park, which falls at the end of Sixth Avenue / Avenue of the Americas, and that the horse had made the journey from Argentina. Outside the frame of the screen image (which is shot in the 2.35:1 aspect ratio of cinemascope ${ }^{16}$ ) but which nevertheless constitutes a key aspect of the conceptual and structural development of the film, are the three equestrian statues to Latin American revolutionary leaders which frame the Artist's Gate entrance to Central Park: Simon Bolivar, liberator of Venezuela; José Martí, Cuban national poet and martyr; and José de San Martin, the Liberator of Argentina and Chile. ${ }^{17}$ In this threshold site (the central gateway to Central Park), there seemed to be inscribed a recognition of the intertwining of art and revolutionary politics: perhaps they are constituted as 'companion species'. That the criollo appears at the Artists' Gate was also significant on a more practical level as it reflected a parallel I saw between the perseverance, commitment and determination demanded by Tschiffely and his two horses to complete the overland journey between Buenos Aires and New York ('zoe is endowed with endurance and resilience' [Braidotti 2006, 110]) and the levels of perseverance, commitment and determination required to realize a film inspired by the story. ${ }^{18}$ In this context, it is important to note another element of the 'political arena' in which the work performs. Over the shoulder of this equine immigrant (imported into the US from Argentina in early February) is Trump Parc, the owner of which real estate having recently assumed the office of US President on an openly anti-immigration ticket. In an increasingly reactionary biopolitical determination of the ground upon which the horse stands - a juridical and political history of capitalism which simultaneously frames (Wolfe 2012) and erases (Berger 1980) the animal - it is nonetheless the animal's 'transversal force', embodied in a nomadic zoe/biopower, which is the source of the criollo's aesthetic and revolutionary potential.

\footnotetext{
${ }^{16}$ The decision to film Criollo in cinemascope evokes the historical correspondence between the horse and film and cinema, from Muybridge Horse in Motion (c. 1886) to the Western, a genre whose origins André Bazin regards as 'almost identical with those of the cinema itself', and accounting for the longevity of the genre (into the 1960s at least) in that it 'must have a secret that somehow identifies it with the essence of cinema'. (Bazin 1971, 140-141) Far from featuring a galloping horse, as depicted in Muybridge's research and in countless Westerns (as Sigfried Kracauer notes, a galloping horse is synonymous with the genre and a 'genuine Western' is unimaginable 'without a pursuit or a race on horseback' [Kracauer 1960, 42]), Criollo nevertheless plays upon this overlap between the figure of the horse and the history of cinema.

${ }^{17} \mathrm{~A}$ further detail with regard to equestrian statues is that the statue of José de San Martin in New York is a copy of the memorial statue to the Argentine leader located in Plaza San Martin, Buenos Aires. An earlier copy of this statue also resides in Triangle Park, Constitution Avenue, Washington, D.C. On the criollo’s passage north from Argentina January-March 2017, the riderless horse was documented at the base of each of these statues in turn, documented in a series of photographs and a second film (in postproduction at the time of writing). For the installation of Criollo in Neue Neue Galerie, documenta 14 in Kassel, 10 June-17 Sept 2017, the film was presented on a large monitor situated between two framed photographs of the horse at the base of the statues to José de San Martin in Buenos Aries and Washington, D.C.

${ }^{18}$ The very presence of the Argentine criollo in New York after several thousand miles of travel resulting from years of planning, applications, setbacks, catastrophes and miracles, represents not so much a feat of artistic endeavor - a 'triumph of the will' à la Leni Riefenstahl, so to speak - as 'the triumph of zoe' (Braidotti 2006).
} 


\section{The Athens-Kassel Ride}

Also inspired by Tschiffely's Ride and the bi-locational structure of documenta 14 was The Athens-Kassel Ride (Figure 2) - an equestrian long ride across Europe. ${ }^{19}$ A mobile, open and participatory, human-equine ensemble performed over 100 days, The Athens-Kassel Ride was developed in collaboration with the experienced Long Riders, Peter van der Gugten and David Wewetzer (member of the Long Riders Guild) and was supported by one of the largest equestrian associations in Germany, the Vereinigung der Freizeitreiter und-fahrer in Deutschland e.V. (VfD). A 'posse' ${ }^{20}$ of 4 riders (Peter van der Gugten, David Wewetzer, Zsolt Szabo, Tina Böche), 5 horses (Artvin, Issy Kul, Paco, Sanchez, Hermes) and two film crew (Samuel Devereux, Mark Wallis) undertook the 3000km trans-European ride, departing from Athens on 9 April and making their way through Greece, Macedonia, Serbia, Croatia, Slovenia, Austria and Germany, arriving at the Fridericianum, Friedrichsplatz, Kassel, 9 July. On its journey, The Athens-Kassel Ride was open to the participation of others of 'whatever race, nationality or creed' (in the words of Tschiffely), or 'whatever being' (in the words of Agamben, 1993); communities which extend to non-human animals as 'companion species' (Haraway, 2003). Long Riders ride according to the Charter of Reken which considers horses as 'partners' and advances the 'freedom to travel the world with horses... crossing today's state borders’ (Charter of Reken, 2017).

Preliminary research for the development of the ride focused upon the practical considerations of sourcing water, hay and field boarding for the horses, linking with equestrian organizations and veterinarians in each country, and also being aware of potential hazards for equines encountering different hay mix or flora which might be ingested; thinking about the animal alongside experienced Long Riders became a thinking about the world. ${ }^{21}$ It was calculated that the ride would take roughly 100 days to complete, including rest days and border days, and that the riders would travel North at the approximate pace of Spring.

The public launch of The Athens-Kassel Ride took place in Athens on the Dionysiou Areopagitou at the foot of the Acropolis. For the event, the Long Riders and horses were joined by four arravani horses and riders from the Arkadian mountain village of Prastos in the Peloponnese. $^{22}$ Together the 8 riders riders and 9 horses formed a visual echo of the ancient Panathenaic festival as depicted on the Parthenon Frieze. Eleven days prior to the launch of this equestrian trek across mainland Europe, the British Prime Minister had written a letter to the President of the European Union triggering Article 50 of the Treaty of Lisbon and thus formalizing the UK's decision to leave the European Union following the outcome of the United Kingdom European Union membership referendum of 23 June 2016. The development of The Athens-Kassel Ride was framed, therefore, by the increasingly tensile architecture of the European Union, and European politics more generally, which saw calls for the reinstatement or re-enforcement of physical and juridical borders across the Schengen and Non-Schengen zones, further exacerbating the plight of millions of refugees fleeing

\footnotetext{
19 The Long Riders produced and maintained their own website for The Athens-Kassel Ride, which documents their daily rides and activities, including the long delays at border crossings: http://www.theathenskasselride.eu/ ${ }^{20}$ I employ the term 'posse' in relation to Hardt and Negri's reading of posse as 'that which produces the chromosomes of its future organization’ (Hardt and Negri, 2000: 407-411; 410).

${ }^{21}$ As Michel Serres somewhat mournfully asks: 'Who now thinks about the world?' (Serres, 2014: 5).

${ }^{22}$ The weekend before the launch of the Ride in Athens, the mountain village of Prastos hosted an inaugural ‘Arravani Festival' (1 April), organized by local Veterinarian, Konstantinos Kourmpellis. The festival promoted the arravani breed with over 50 horses and riders from across the region, and also included participants from arravani equestrian societies in Germany. The festival also celebrated the departure of the Greek horse 'Hermes' (specially sourced for the Ride) as he embarked upon his journey from the Arkadian mountains to Kassel.
} 
Syria, Libya and Afghanistan, among other war zones. The etymology of 'refugee' is 'to flee' and this (forced) deterritorialization of the refugee in a multiplicity of lines of flight fabricates a potential plane of consistency where species meet. Equestrian scholars inform us that the horse is essentially 'a flight response animal' and that its ability to run at speed from predators was essential for its survival and evolution. ${ }^{23}$ In addition to a propensity for flight, horses also possess an immanent nomadism, manifest in a desire for constant movement. ${ }^{24}$ In Deleuze and Guattari's terms, such constant animal motion would constitute a vector of deterritorialization. It is in these terms that we might identify a relation between two figures which, for Agamben, constitute 'biopolitical thresholds': the animal and the refugee (Agamben 1998, 131-35). ${ }^{25}$

The 'vagabond trail' route of The Athens-Kassel Ride from Greece through the Balkans to Northern Europe, draws obvious parallels between the documented journey of a handful of horses with the often undocumented journeys of hundreds of thousands of refugees; an association furthered by the fact that, despite aspirations of borderless riding according to the Charter of Reken, both riders and horses spent six days stuck on the SerbianCroatian border attempting to negotiate the re-entry of man and animal into the EU. To dwell on the surface of such correspondences between the movement of animal and refugee is perhaps to accept the limitations of contemporary art in the face of the scale of a humanitarian catastrophe. Nonetheless, such associations perhaps point to deeper correspondences and resonances beneath the surface. To remark upon the overlapping conceptual territories of animals and refugees is not simply to recognize the 'inhumanity' of living conditions in makeshift border camps and detention centres, of summary deportation orders and of countless drownings at sea; nor is it simply to repeat that in the denial of access to basic human rights, refugees are often treated as animals. It is to recognize that such practices are evidence of biopolitical 'zones of indeterminacy' between animal and human life, between zoe and bios, a transverality which delineates 'a mobile border within living man' (Agamben 2004, 15) - a mobility embodied for Braidotti in a 'nomadic postanthropocentric philosophy' (Braidotti 2006, 103). As the biopolitical substrate of 'bare life', the 'interlacement of zoe and bios', Agamben augurs, 'seems to define the political destiny of the West' (Agamben 1998, 188).

\section{Animal Envoys}

Animals first entered the imagination as messengers and promises. (Berger 1980, 12)

Criollo and The Athens-Kassel Ride, commissioned for documenta 14, are the latest

${ }^{23}$ The Proceedings of the British Equine Veterinary Association (BEVA) relate:

The horse evolved in an environment where it was a prey species; therefore its overriding aim is to avoid being eaten and, in order to do this, its survival techniques are based on detection of any possible predators and its subsequent escape from them, for which the horse needs acute senses, quick reactions and the ability to run fast. (Harris et al, 1999, np);

See also Jethro Tull Jr, ‘Of Work Animals: Bovines and Equines’, Horse-Hoeing Husbandry [1750], Fifth Edition by Aaron Brachfield and Mary Choate (Colarado: Coastalfields Press, 2010): 'As prey animals, both equines and bovines naturally flee when approached.' (Tull 2010, 545); Budiansky (1997): ‘... Pliocene horses (beginning 5 million years ago)... as grassland animals, these grazing horses were more exposed to predators and had to be able to flee.' (Budiansky 1997, 21).

${ }^{24}$ As the BEVA Proceedings inform us: 'The horse is... strongly motivated to keep moving, not necessarily at high speeds, but certainly over some distance...' (Harris et al. 1999, np).

${ }^{25}$ In a different context, this correspondence is found in the combined form of the 'animal refugee' in Armstrong (2008). See Chapter 5. 'Animal Refugees in the Ruins of Modernity'. 
works in the ongoing Envoy series of site-specific actions, gestures and interventions performed across the globe. Works in the Envoy series often have a 'bi-locational' and transit structure; for example, A copy of Thomas More's Utopia gifted to the United Nations, New York (2000) was a companion work to A copy of Thomas More's Utopia gifted to the International Court of Justice, the Hague (2000); The Stars \& Stripes thrown into the Hudson River, New York (2000) was a companion work to A copy of the Collected Works of Marx \& Engels thrown into the Neva River, St. Petersburg (1998). Marked by a sense of utopian apostasy, these works were a response to the reported failure of 'grand narratives' and a questioning of the political or social role of the artist as a conveyor of messages or producer of meanings; for example, The Destiny of the World, a sealed package thrown into the Barents Sea (2001). This dialectic of desire and uncertainty is embodied in the figure of the artist as 'envoy' sent by an unknown power for an unspecified end. The structural duality of Envoy is mirrored in the accumulation of double meanings in the terms orbiting the work: 'utopia' (More's coinage of 'good place' and 'no place'), 'gift' (translating as both 'present' and 'poison'), to 'throw' (to discard, reject) and to 'cast' (to copy, preserve), and 'envoy' itself (being both the 'messenger' and the 'message'). Although I carried out the majority of the actions, it is important to recognize that the 'envoy' is not always me. ${ }^{26}$ In this respect, Criollo and The Athens-Kassel Ride, mark a significant development in this series in that the 'envoy' (as figure of messenger / angel-messenger) has undergone a further transposition: from the human to the non-human animal envoy, in this context the horse. According to Berger, animals first enter human imagination as symbolic 'messengers' and that 'the essential relation between man and animal was metaphoric' and 'magical' (Berger 1980, 16). On a more materialist and mercantile level, Ulrich Raulff reminds us, the horse-as-courier, alongside their human counterparts, performed an unduly neglected role in the history of communication and the systematic relay of messages:

Even historians and theorists of communication... [tend] to overlook - together with the human messengers - the most important envoy and courier of such messages.' (Raulff 2017, 346. My italics)

As works in the Envoy series Criollo and The Athens-Kassel Ride may ultimately be read as human-equine allegory in the form of a participatory artwork in the genre of 'delegated performance' (Bishop, 2012). However, horses and riders are actualities rather than allegories, and the process was characterized by collaboration as opposed to delegation.

\section{The Transit of Hermes}

Living inside The Athens-Kassel Ride, like a parasite ${ }^{27}$, and forming a subtitle to the work, was another 'envoy' artwork: The Transit of Hermes (Figure 3). The Long Riders and their horses - a variety of breeds, Kabardine, Karabakh, Haflinger, Criollo - were accompanied by a 5-year-old arravani horse which I named 'Hermes', after the Greek god of border crossings.

Arravani are a Greek gait horse which are now in decline, with the last remaining herds being in Greece and Germany. Hermes, a horse from the Arkadian mountains of the

\footnotetext{
${ }^{26}$ See Birrell (2014).

${ }^{27}$ Michel Serres's study of parasites and parastical relations (Serres, 2007) provides an interesting critical perspective on the relation of the development of individual artworks to their host contexts and also on the context of documenta 14 being 'hosted' in Athens, as well as a reading of the wider economic relations between Germany and Greece more generally.
} 
Peloponnese, was not to be ridden but only to carry light equipment necessary for the ride. Hermes, therefore, was a crucial physical and metaphorical figure of the Ride, which over the approximate 100 days of its duration enacted a third space of documenta 14, inhabiting a mobile terrain between Athens and Kassel - a nomadic metaxy associated with the arravani's namesake. The mythical Hermes was an emissary and messenger of the Gods and a central figure in the thought of Michel Serres, whose writings (alongside those of Rilke, Heidegger, Derrida, Donna Haraway, Lewis Hyde and others) traveled alongside the development of the projects for documenta 14:

I did not choose Hermes as my totem, emblem or theorem for speculative reasons alone. Nor with the historical foresight, necessary in philosophy, that made me say a quarter of a century ago that we were at the beginning of an era in which Hermes would occupy the dominant position over Prometheus, although the latter had held sway over our world and thinking for over a hundred years. I took him for my ensign also because he flies, the first angel, with wings on his feet. Hermes precedes all other angels, just as they leave traces of Hermes in their wake. (Serres 2008, 315)

Serres considers Hermes as 'the god of the crossroads' (Serres 1982, 14), developing a five volume series of reflections on the theme of Hermes, addressing through mathematics and philosophy issues of communication, translation, distribution and interference, and which first appeared in 1969. Published the same year, Norman O. Brown's account of the myth, casts Hermes as an agent of political emancipation; painting the antagonism between Hermes and Apollo as an allegory of class conflict in Athens in the $6^{\text {th }}$ Century BC: 'The theme of strife between Hermes and Apollo translates into mythical language the insurgence of the Greek lower classes and their demands for equality with the aristocracy.' (Brown 1969, 88) For Lewis Hyde, building, in part, upon Norman O. Brown's account, Hermes is an ambiguous, 'polytropic' ${ }^{28}$ character - a 'mercurial' figure, as per his Roman namesake forever occupying a 'double field of action' (Hyde 2008, 207), eternally in transit between the worlds of gods and humans, the living and the dead. In his journey from Athens to Kassel, then, Hermes was not only in transit between Greece and Germany - traversing a zigzagging diagonal line which traces the historical and contemporary tensions of Europe - but in constant 'double motion' (Hyde 2008, 209) between myth and materiality, economics and politics, philosophy and action, humans and animals. For this reason in the resulting film, The Transit of Hermes, the horse also appears doubled in a mirrored image, slow-motion, splitscreen projection in which the horse is perpetually walking in hermetic silence, towards or away from himself, in a journey of perpetual motion. Hermes belongs only to the journey:

The journey is at home while underway, at home on the road itself, the road being understood not as a connection between two definite points on the earth's surface, but as a particular world. It is the ancient world of the path... the genuine roads of the earth. For, unlike Roman highways which cut unmercifully straight through the countryside, they run snakelike, shaped like irrationally waved lines, conforming to the contours of the land, winding, yet leading everywhere. Being open to everywhere is part of their nature. Nevertheless, they form a world in its own right, a middle-domain, where a person in that volatized condition has access to everything. He who moves about familiarly in this world-of-the-road has Hermes for his God... Hermes is constantly underway: he is enodios ("by the road") and hodios ("belonging to a journey”), and one encounters him on every path. He is constantly in motion... His role

\footnotetext{
${ }^{28}$ In a footnote on his translation of 'The Homeric Hymn to Hermes', Lewis Hyde relates that Hermes was “"cunning," "versatile,” "much travelled,” "polytropic”: poútropon (literally turning many ways)'. (Hyde, 2008: 317)
} 
as leader and guide is often cited and celebrated, and, at least since the time of the Odyssey, he is also called angelos ("messenger”), the messenger of the Gods. (Kerenyi 1986, 14-15)

Like Ahi, the Argentine criollo 'transposed' ${ }^{29}$ from Buenos Aires to New York, Hermes is a courier, an intermediary, an animal envoy, an angel messenger. The apparition of the animal - migrant, messenger, refugee, envoy, gift - is transposed into the mercurial figure of the angel: 'Hermes precedes all other angels, just as they leave traces of Hermes in their wake.'(Serres 2008, 315) ${ }^{30}$

For Luce Irigaray, the angel is 'that which unceasingly passes through the envelope(s) or containers, goes from one side to the other' (Irigaray 2004, 15). They appear as messenger 'come to herald the arrival of a new birth, a new morning' and ultimately a new 'ethics evoked by art'. (Irigaray 2004, 15-16) In addition to the role of augur or envoy, and in relation to the present context, Massimo Cacciari, in his study The Necessary Angel (1994), avers: 'The creature that on earth comes closest to... the Angel... is the animal.' (Cacciari 1994, 83):

Animal and Angel appear assured in and of their space, appropriately disposed in it: nothing draws them into the future, no force can transcend their present... The gaze of the animal enjoys the same autonomy from spatial fragmentation and temporal succession as that enjoyed by the angelical games in the Areopagite and Dante... the animal can be for us an image of the Angel... The animal is our angel of the Angel. (Cacciari 1994, 89-90. My italics.)

'Angels and animals at the same time?' (Serres 1995, 162) queries Michel Serres in his study Angels: A Modern Myth (1995):

... is it possible for an angel to lead a double life?

An angel can even lead multiple lives, my ironical friend, because he may be a vulture or a kestrel - a creature of both heaven and earth, but also of flesh and of spirit, of transparent abstraction and of visible concreteness (Serres 1995, 162-3)

Berger draws a similar parallel in his consideration of 'animals as an intercession between man and his origin...' (Berger 1980, 15). ${ }^{31}$ Animals further resemble angels in that both share an ambiguous resemblance to their human counterparts: 'Animals interceded between men

\footnotetext{
${ }^{29}$ My use of the term 'transposed' is informed by previous works which transposed music, film and site in installations such as Duet (2013) and Sonata (2014), exhibited in Winter Line, Kunsthalle Basel (2014) and Where Language Ends, Talbot Rice Gallery (2015), exhibitions made in collaboration with David Harding; it is also informed and advanced by a reading of Rosi Braidotti: 'The term "transpositions" has a double source of inspiration: from music and from genetics. It indicates an intertextual, cross-boundary or transversal transfer, in the sense of a leap from one code, field or axis into another, not merely in the quantitative mode of plural multiplications, but rather in the qualitative sense of complex multiplicities. It is not just a matter of weaving together different strands, variations on a theme (textual or musical), but rather of playing the positivity of difference as a specific theme of its own. As a term in music, transposition indicates variations and shifts of scale in a discontinuous but harmonious pattern. It is thus created as an in-between space of zigzagging and of crossing: nonlinear, but not chaotic; nomadic, yet accountable and committed; creative but also cognitively valid; discursive and also materially embedded - it is coherent without falling into instrumental rationality.' (Braidotti 2006, 5)

${ }^{30}$ Hyde refers to Hermes as an 'awakening angel' (Hyde 2008, 209). In an echo of Hermes's mercurial identity, 'The dimension of the Angel', Massimo Cacciari asserts, 'is ou-topic. Its place is the Land-of-no-where, the mundus imaginalis...' (Cacciari 1994, 1).

${ }^{31}$ Berger’s comments on animal ‘intercession’ further invite a parallel between the animal and the angel. However, Cacciari, drawing upon Luther, warns: 'One should not confuse the role of intermediary, of metaxy, with that of intercession.' (Cacciari 1994, 95, n2). Nevertheless, outside Lutheran doctrine, the concept of angelic intercession remains a widespread Christian concept. My purpose in pursuing a correspondence between the animal and the angel, here, however, is less to outline theological than theoretical perspectives upon animals.
} 
and their origin because they were both like and unlike man.' (Berger 1980, 15) 'Every Angel is terrible.' (Rilke 1975, 25). If Rilke's claim in the first of the Duino Elegies is true, it is not on account of a divine distance but in the proximity of a more pressing existence. Equally, animals are somehow able to divine our vulnerability and unveil the innermost human secret 'that we don't feel very securely at home / in this interpreted world' (Rilke 1975, 25). The ultimate fate of our co-existence, therefore, is to be abandoned by angel, human and animal alike. 'To invoke the posthuman', warns Brian Massumi, 'is to invoke the postanimal.' (Massumi 2014, 91) - and equally to invoke the postangel. This is why both Criollo and The Athens-Kassel Ride: The Transit of Hermes seek to inhabit a 'zone of indeterminacy' between human and non-human worlds. These works share a bi-locational structure which each frames the figure of an animal in transit between two entangled and indeterminate worlds, tracing the path of the horse as both 'companion' in the co-evolution of species and 'spectre of the nonhuman' (Morton 2017); the necessary angel of the precarious Anthropocene: gift, envoy, messenger, migrant, refugee.

\section{Bibliography}

Agamben, Giorgio. 1993. The Coming Community. Translated by Michael Hardt. Minneapolis: University of Minnesota Press, Agamben, Giorgio. 1998. Homo Sacer: Sovereign Power and Bare Life. Translated by Daniel HellerRoazen. Stanford: Stanford University Press

Agamben, Giorgio. 2004. The Open: Man and Animal. Translated by Kevin Attell. Stanford: Stanford University Press

Agamben, Giorgio. 2002. Remnants of Auschwitz: The Witness and the Archive. Translated by Daniel Heller-Roazen. New York: Zone

Agamben, Giorgio. 2009. What is an Apparatus? And Other Essays. Translated by David Kishik and Stefan Pedatella. Stanford: Stanford University Press

Aristotle. 1962; Rev. Ed., 1981. The Politics. Translated by T. A. Sinclair. Harmondsworth: Penguin 
Armstrong, Philip. 2008. What Animals Mean in the Fiction of Modernity. London: Routledge Bazin , André. 1971. What is Cinema? Volume II. Translated by Hugh Gray. Berkeley: University of California Press

Berger, John. 1980. 'Why Look at Animals', About Looking. New York: Pantheon

Birrell, Ross. 2014. An Envoy Reader. London: LemonMelon

Birrell, Ross, Ron Broglio. 2011. 'Art and the Animal Revolution (Editorial).' Art \& Research: A Journal of Ideas, Contexts and Methods, 4 (1). Accessed June 12, 2017

Bishop, Claire. 2012. Artificial Hells: Participatory Art and the Politics of Spectatorship. London: Verso

Borges, Jorge Luis. 1999. Selected Non-Fictions. Edited by Eliot Weinberger. Translated by E. Allen, S. J. Levine, and E. Weinberger. New York: Viking

Braidotti, Rosi. 2006. Transpositions: On Nomadic Ethics. Cambridge: Polity

Broglio, Ron. 2011. Surface Encounters: Thinking with Animals and Art. Minneapolis: University of Minnesota Press

Brown, Norman O. 1969. Hermes the Thief: The Evolution of a Myth. New York: Vintage

Budiansky, Stephen, 1997. The Nature of Horses: Their Evolution, Intelligence and Behaviour. London: Phoenix

Cacciari, Massimo. 1994. The Necessary Angel, translated by Miguel E. Vatter. New York: SUNY Charter of Reken. 2017. Charter of Reken: Travelling with horses without boundaries. Accessed: March 1, 2017. http://www.theathenskasselride.eu/uploads/7/7/6/0/7760989/charta of reken.pdf Deleuze, Gilles and Félix Guattari. 1988. A Thousand Plateaus: Capitalism and Schizophrenia. Translated by Brian Massumi. London: Athlone Press

Deleuze, Gilles and Félix Guattari. 1994. What is Philosophy? Translated by Hugh Tomlinson and Hugh Burchell. New York: Columbia University Press

Deleuze, Gilles and Claire Parnet. 1989. Abécédaire. Accessed November 17, 2017.

https://vimeo.com/108004617

Derrida, Jacques. 2008. The Animal That Therefore I Am. Edited by Maries-Louise Mallet. Translated by David Wills. New York: Fordham University Press

Derrida, Jacques. 2009. The Beast and the Sovereign, Volume 1. Translated by Geoffrey Bennington Chicago: University of Chicago Press

Enwezor, Okwui, et al, eds. 2002. Creolité and Creolization: Platform 3_Documenta 11. Berlin: Hatje Cantz

Foucault, Michel. 1981. The History of Sexuality, Volume 1: An Introduction. Translated by Robert Hurley. Harmondsworth: Penguin

Glissant, Édouard. 1989. Caribbean Discourse: Selected Essays. Translated by J. Michael Dash. Charlottesville: University of Virginia Press

Haraway, Donna. 2003. The Companion Species Manifesto: Dogs, People, and Significant Otherness. Chicago: Prickly Paradigm Press

Hardt, Michael and Antonio Negri. 2000. Empire. Cambridge, Mass.: Harvard University Press

Harris, Pat A., et al. 1999. 'The Natural Horse and Unnatural Behaviour', Proceedings of the BEVA

Specialist Days on Behaviour and Nutrition (Equine Veterinary Journal). Accessed: November 26,

2017. https://www.quia.com/files/quia/users/medicinehawk/1507-Behavior/The-Natural-Horse.pdf

Hayman, Ronald. 1981. Nietzsche: A Critical Biography. London: Quartet

Heidegger, Martin. 1992. Parmenides. Translated by André Schuwer and Richard Rojcewicz.

Bloomington: Indiana University Press

Hernández, José. 1967. The Gaucho Martín Fierro. Translated by Walter Owen. Buenos Aires: Instituto Cultural Walter Owen

Hyde, Lewis. 2008. Trickster Makes This World: How Disruptive Imagination Creates Culture. Edinburgh: Canongate

Irigaray, Luce. 2004. An Ethics of Sexual Difference. Translated by Catherine Porter and Carolyn

Burke. London: Continuum

Kerényi, Karl. 1986. Hermes, Guide of Souls: The Mythologem of the Masculine Source of Life. Translated by Murray Stein. Dallas: Spring

Kracauer, Sigfried. 1960. Theory of Film: The Redemption of Physical Reality. London: Oxford University Press 
Latimer, Quinn and Adam Szymczyk, eds. 2017. Documenta 14 Daybook. Munich: Prestel Latour, Bruno. 1999. Pandora's Hope: Essays on the Reality of Science Studies. Cambridge, Mass.: University of Harvard Press

Massumi, Brian. 2014. What Animals Teach Us about Politics. Durham: Duke University Press Morton, Timothy. 2017. Humankind: Solidarity with Non-Human People. London: Verso Porter, Roy and Sylvana Tomaselli, eds. 1989. The Dialectics of Friendship. London: Routledge Ramos, Filipa, ed. 2016. Animals. London: Whitechapel

Raulff, Ulrich. 2017. Farewell to the Horse: The Final Century of Our Relationship. Translated by Ruth Ahmedzai Kemp. London: Allen Lane

Rilke, Rainer Maria. 1975. Duino Elegies. Translated by J. B. Leishman and Stephen Spender. London: Chatto \& Windus

Santner, Eric L. 2006. On Creaturely Life: Rilke, Benjamin, Sebald. Chicago: University of Chicago Press

Serpell, James. 2008. In the Company of Animals: A Study of Human-Animal Relationships. Cambridge: Cambridge University Press

Serres, Michel. 1995. Angels: A Modern Myth. Edited by Philippa Hurd. Translated by Francis Cowper. Paris: Flammarion

Serres, Michel. 1982. Hermes: Literature, Science, Philosophy. Edited by Josié V. Harari and David F. Bell. Baltimore: Johns Hopkins University Press

Serres, Michel. 2007. The Parasite. Translated by Lawrence R. Schehr. Minneapolis: University of Minnesota Press

Serres, Michel. 2008. The Five Senses: A Philosophy of Mingled Bodies (I). Translated by Margaret Sankey and Peter Cowley. London: Continuum

Serres, Michel. 2014. Times of Crisis: What the Financial Crisis Revealed and How to Reinvent our Lives and Future. Translated by Anne-Marie Feenberg-Dibon. London: Bloomsbury

Tschiffely,

Aimé Félix. 1933. Tschiffely’s Ride. London: Heinemann

Tschiffely, Aimé Félix. 1943. The Tale of Two Horses. London: Hodder and Stoughton

Tull Jr, Jethro. 2010. Horse-Hoeing Husbandry [1750], Fifth Edition by Aaron Brachfield and Mary Choate. Colarado: Coastalfields Press

Wolfe, Cary. 2013. Before the Law: Humans and Other Animals in a Biopolitical Frame. Chicago: University of Chicago 